\title{
Koreans rustle up madness-resistant cows
}

\section{David Cyranoski, Tokyo}

Cloned cattle that are said to be resistant to mad cow disease have been born in Korea. Whether milk or meat from such cows will ever reach supermarkets is unclear. But some experts are enthusiastic about the prospects of using such animals as 'bioreactors' to produce drugs for human use.

Mad cow disease, or bovine spongiform encephalopathy (BSE), is thought to be caused by prions, aberrant forms of a normal protein called PrP. Prions convert other PrP to their own misshapen form, causing plaques of protein to accumulate, killing nearby nerve cells. More than 130 people, most of them in Britain, have died from BSE since the disease was found to have crossed over to humans in 1996.

Today, officials in many countries keep BSE out of the human food chain by monitoring slaughterhouses and cattle for signs of infection. But Korean researchers led by Woo-Suk Hwang, a cloning specialist at Seoul National University's College of Veterinary Medicine, claim that their calves could make BSE a thing of the past. On 10 December, they announced the birth in November of four 'BSE-proof' cloned calves.

The clones were made from a cell carrying additional genes for PrP that had been mutated so that although the protein still binds to prions, it resists being converted to the aberrant form. Hwang's team also introduced promoter DNA that boosts the production of this altered $\mathrm{PrP}$ well above normal levels, minimizing the chance that prions can find and convert normal PrP. A similar method has been used previously in mice (V. Perrier et al. Proc. Natl Acad. Sci. USA 99, 13079-13084; 2002), where it does seem to protect against prion infection.

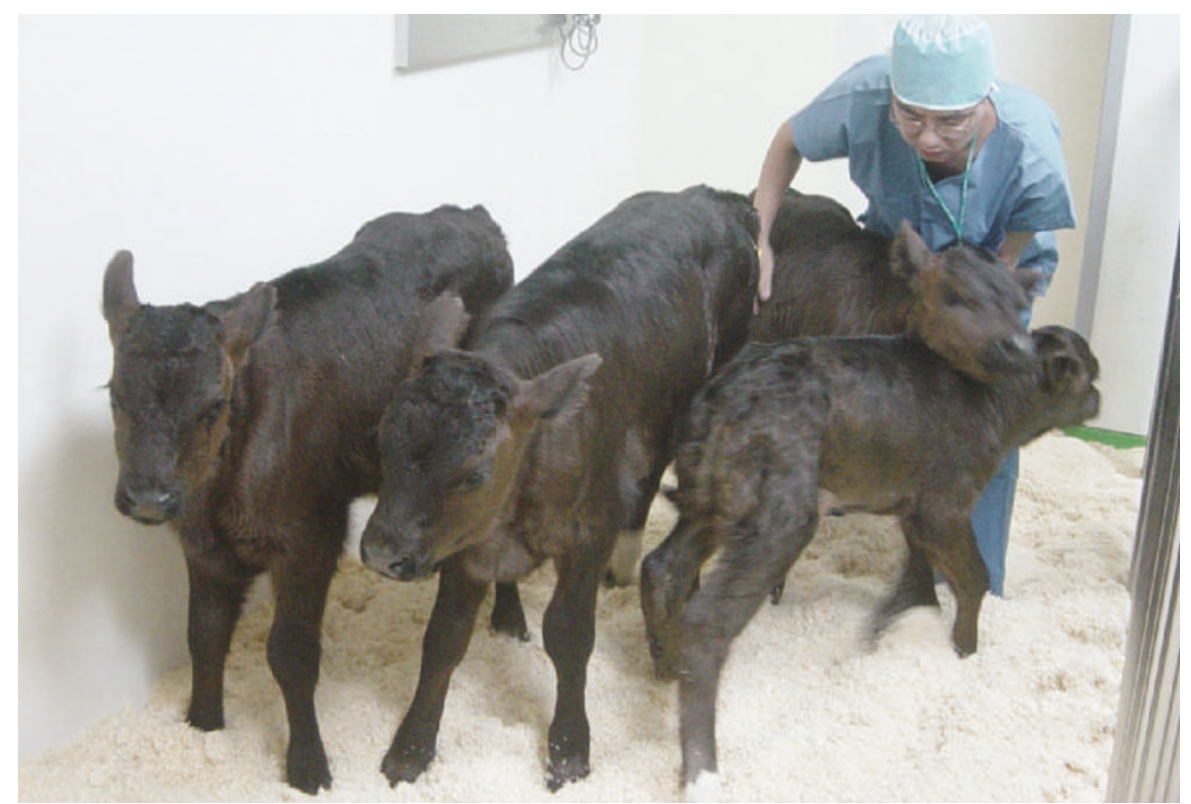

Beefed up: Korean researchers believe tests will show that their cloned cows are resistant to BSE.

Hwang says that more testing is needed. From February, the calves will be sent to a new BSE facility in Tsukuba, Japan, where they will be given feed containing BSE-inducing prions to see if they are truly immune. The group will also test another group of cloned cattle, due to be born in January, in which the gene for PrP has been knocked out altogether, giving prions nowhere to get a foothold.

"If we have positive results after three to five years we will try to make these cattle commercially available," says Hwang. Last week, the group applied for a global patent covering both methods of generating the clones.

The tests must look at whether the treatments affect the animals' health. The function of $\mathrm{PrP}$ is unknown, and knockout mice seem to be healthy. "But the protein's function might be different in mice and cattle," warns Eckhard Wolf, who studies transgenic animals at the University of Munich, Germany.

Wolf doubts that transgenic BSE-proof cows will be important for agriculture, given the cost of producing transgenic animals and the huge investment in conventionally bred cattle. But he does see an opportunity to create cows engineered to produce therapeutic proteins in their milk. Fears about BSE could deter regulators from approving such drugs for use, Wolf suggests. "Transgenic cows that cannot be infected with BSE should be clinically more acceptable," he says.

\section{EMBO chief threatens to quit over funding crisis}

\section{Quirin Schiermeier, Munich}

A freeze on funding for the European Molecular Biology Organization (EMBO) has prompted its executive director, Frank Gannon, to threaten resignation unless prospects improve.

The organization promotes molecular biology through postdoctoral fellowships, conferences and workshops, and is funded by the 24 member countries of the European Molecular Biology Conference.

This summer, the conference unanimously accepted a five-year plan outlining EMBO's funding priorities for 2004-08. The plan includes an extension of EMBO's two-year fellowship programme to three years. This programme supports the training of young postdoctoral biologists and allows them to travel between labs.

But it now seems that there will not be enough money to pull such plans off. Last month, the conference's four largest members - Germany, Britain, France and Italy - unexpectedly rejected any increase in EMBO's budget for 2004-06.

The situation is all the more worrying, says Gannon, because the number of applicants for the fellowship programme has leapt in the past two years, probably because of the poor job market for biologists in countries such as Germany, France and Spain. But as the number of applicants has risen, the money to support them remains the same. The success rate for applicants has fallen from $22 \%$ before 2001 to below $15 \%$ now, and may continue to fall.
"I would not be able to stand over an inadequately funded programme, as it would damage EMBO's reputation," says Gannon.

EMBO asked conference members for a budget increase from $€ 10.8$ million (US\$13.2 million) to $€ 15.5$ million in 2006 . The contribution of different countries is linked to economic performance, so Britain would shoulder the biggest rise, of some $€ 1$ million by 2006 - a $44 \%$ increase.

"We didn't say that we couldn't agree to any increase, but we felt that $44 \%$ is too much," says David Smith, an official at the UK Medical Research Council, which funds Britain's membership of the conference.

Conference members will discuss the possibility of obtaining further funding at a special meeting in January. 